\title{
Prevalence of cellular leiomyoma and partially cellular leiomyoma in postoperative samples — analysis of 384 cases
}

\author{
Dobrosława L. Sikora-Szczęśniak \\ Department of Obstetrics and Gynecology, Radom City Hospital, Poland
}

\begin{abstract}
Objectives: The aim of the study was to evaluate the prevalence of cellular leiomyomas and partially cellular leiomyomas in postoperative samples.

Material and methods: A total of 2144 cases of uterine leiomyomas were diagnosed in postoperative samples at the Department of Obstetrics and Gynecology, RSzS, Radom, Poland, between 1998 and 2014. We analyzed 384 cases which were subdivided into 4 groups, taking into account the co-occurrence of leiomyomas and/or endometriosis. The following variables were investigated: age, weight, BMI, parity, type of surgical procedure, prevalence of atypical and borderline tumor forms, and concomitant malignancy of the reproductive system.

Results: The prevalence of cellular leiomyomas and partially cellular leiomyomas was estimated at $17.9 \%$. Nulliparous patients were significantly more numerous in the subgroups without endometriosis. Concomitant malignancy of the reproductive system was $>2$ fold more commonin the subgroups with endometriosis as compared to the other subgroups.

Conclusions: The fact that cellular leiomyomas have a varying degree of cell atypia, together with clinical observations reported in the literature, support the view that cellular leiomyomas and partially cellular leiomyomas can progress to malignant leiomyosarcoma (LMS). Hysterectomy and the subsequent follow-up should be the mainstay of therapy for cellular leiomyoma. Conservative management (myomectomy) should be recommended only tothose patients who wish to preserve their fertility.
\end{abstract}

Key words: cellular leiomyoma, partially cellular leiomyoma

\section{INTRODUCTION}

Leiomyomas are non-epithelial, mesenchymal, benign monoclonal tumors, formed by smooth muscle cells of the myoblast or myometrial vessel cell and the stroma composed of fibrous connective tissue [1]. Based on the histopathological analysis of the extirpated uteruses, leiomyomas are detected in almost $77 \%$ of women in the reproductive age [2]. Clinically, leiomyomas are diagnosed in $25 \%$ of all women, $30-40 \%$ of women $>40$, and $40 \%$ of women $>50$ years of age [3]. Each leiomyoma - regardless of it being a part of a cluster or a single uterine lesion - develops from a single, initially neutral precursor cell which had mutated [4]. Uterine leiomyomas are the most common benign lesions in the female population and the most frequent pathology of the genital organs in women of the reproductive age. The hormone-dependent nature of leiomyomas has been demonstrated by their rare occurrence after menopause and surgical gonadectomy, as well as lack of cases before puberty. In case of uterine leiomyomas, it is different from hormone-dependent nature of the myometrium with regard to the quantity and quality of estrogen receptors, quantity and quality of progesterone receptors - which are several times more numerous in leiomyomatic cells, expression and activity of aromatase, and the intensity of proliferation and apoptosis [5, 6].

Genetic background is one of the identified risk factors for the disease [7]. Significantly higher expression of the vascular endothelial growth factor A (VEGF-A) was found in 
the group with family history of leiomyomas [8]. Autosomal dominant inheritance has been found, among others, in cases of co-occurrence of cutaneous and uterine leiomyomas in as many as $98 \%$ of the affected women. The condition, known as the Reed's syndrome or MCUL1 (multiple cutaneous and uterinae leiomyomata), is associated with the mutation of the fumarase encoding gene (an enzyme of the Krebs Cycle, localized on chromosome 1) [9]. Cytogenetic anomalies, detected in approximately $40 \%$ of all leiomyomas, include among others translocation, trisomy, and deletion $[10,11]$. Chromosomal aberrations are found in the cells of submucosal, subserosal, and intramural leiomyomas $(12 \%, 29 \%$, and $35 \%$, respectively). Aberrational diversity indicates a multitude of genetic mechanisms associated with the formation of leiomyomas. Elevated risk for uterine sarcomas and higher incidence of postmenopausal tumors have been reported for female carriers of the mutation [12]. Hoffman et al., are of the opinion that dysregulation of apoptosis and proliferation, resulting from genetic abnormalities, plays a key role in the development of uterine fibroids [13]. Also, results of in vitro tissue studies have demonstrated a role of mediating factors such as cytokines and growth factors, through which hormones may affect tumor growth. Estrogen and progesterone regulate the expression of cytokines and growth factors which modify the activity of other transcription factors. In case of dysregulated cytokine and growth hormone production, the following processes: increasing frequency of cell division, cell hypertrophy, and extracellular matrix (ECM) accumulation, individually or all together, may be observed [6]. Members of the transforming growth factor beta (TGF- $\beta$ ) superfamily play an important role in the formation of leiomyomas, both as inhibitors, tumor growth stimulators, and regulators of their fibrosis. They also affect the tumor microenvironment as immunosuppressive factors and angiogenesis stimulators [14, 15]. Their activity - especially that of TGF- $\beta 3$ - was confirmed in the transformation of a normal uterine muscle cell to its malignant phenotype. Overexpression of TGF- $\beta 3$ plays a vital role in the formation of ECM, characteristic for uterine fibroids $[16,17]$. Proteins from the BMP-1/mTLD (bone morphogenetic protein 1/mammalian tolloid) subfamilyare important regulators of ECM formation as well as formation of the antiangiogenic factor from prelecan - a component of the basement membrane [1].

Cellular fibroids are the most common (5\%) among the numerous histological subtypes of leiomyomas [18]. Their histopathological examination revealed cell abundance, with a small component of connective elements, little or no atypia, absence of coagulative necrosis, and the mitotic count of $<5 / 10$ HPF (microscope field of view at 40x magnification). Immunohistochemical analysis - for desmin, $\mathrm{CD}, \mathrm{H}$-caldesmon - are used to differentiate cellular leio- myomas from stromal tumors of the uterine corpus and leiomyosarcomas (LMS). At present, it is believed that in the absence of coagulative necrosis, tumors with $<10$ mitoses/10 HPF, without cell polymorphism, have a good prognosis, whereas tumors with $>10$ mitoses/10 HPF, without cell polymorphism, are malignant.Malignant transformation is suspected in case of cellular leiomyomas with the mitotic index of $\geq 5$ and accompanying atypia [19]. Nevertheless, the literature emphasizes the challenge of unambiguous classification and histopathologic evaluation of various subtypes of leiomyomas, as well as the prognosis for their clinical course.

\section{OBJECTIVES}

The aim of the study was to evaluate the prevalence of cellular leiomyomas (CL) and partially cellular leiomyomas in postoperative samples of uterine leiomyomas collected over the course of 17 years.

\section{MATERIAL AND METHODS}

A total of 2144 cases of uterine leiomyomas were diagnosed in postoperative material obtained during surgeries and procedures performed at the Department of Obstetrics and Gynecology, RSzS, Radom, Poland, between 1998 and 2014. Uterine leiomyomas and leiomyomas with coexisting endometriosis were detected in 1308 (61.00\%) and $836(39.00 \%)$ of the samples, respectively.

Patients were deemed eligible for surgery based on gynecological and ultrasound examinations, as well as histopathological evaluation of uterine scrapings. The material for the study consisted in surgical protocols, results of histopathologic evaluations (diagnostic, preliminary and final) from the medical charts, hospital charts, results of laboratory studies, and data on additional treatments and check-ups at out-patient ob-gyn and oncology clinics.

The final diagnosis was made at the Department of Pathomorphology, RSzS, Radom, Poland. Microscopic evaluation of the mitotic index, presence of atypia and tumor necrosis was performed. Clinic analysis was conducted in the 384 cases with confirmed cellular leiomyomas and partially cellular leiomyomas. The following 4 subgroups were identified:

- group I - cellular leiomyoma $(\mathrm{CL})(\mathrm{N}=92)$;

- group II - CL with endometriosis $(\mathrm{N}=32)$;

- group III - partially cellular leiomyomas and/or CL with leiomyoma ( $\mathrm{N}=152)$;

- group IV - partially cellular leiomyomas and/or CL with leiomyoma and endometriosis ( $\mathrm{N}=108)$.

Partially cellular leiomyomas were also included into the analysis, bearing in mind that each such case might in fact be a preliminary variant form of $\mathrm{CL}$, which is supported by their known coexistence with malignant tumors of the 
genital tract, especially LMS. The groups with concurrent endometriosis of the uterine corpus were analyzed separately due to significantly higher prevalence of malignant neoplasms of the genital tract among these cases.

The analysis took into account patient age, weight, BMI, parity (delivery, miscarriage, ectopic pregnancy), the need for blood and blood products, different coexisting histopathologic variants of cellular leiomyomas, coexistence of leiomyomas and/or endometriosis, or malignant tumors with cellular leiomyomas, and type of surgery (including myomectomy during cesarean section). The results are presented in Tables 1-7.

Statistical analysis was performed using the Gretl software (shareware, free license). ANOVA was used to determine the statistical significance of the differences between the groups of patients, while the t-student test verified intergroup differences. The $p$-value of $<0.05$ was considered as statistically significant.

\section{RESULTS}

Mean patient age in the four subgroups was 47.7 years. Statistically significant differences were observed between women from groups II and III, as well as III and IV (Tab. 1).

Differences in weight did not reach statistical significance but the difference in BMI was significantly different in patients from groups I and II (Tab. 2).

Obstetric data (delivery, miscarriage, ectopic pregnancy) are presented in Table 3. Statistically significant differences - only with regard to the number of deliveries - were found between women from groups I and II, II and III, as well as III and IV.
Packed red blood cells and fresh frozen plasma were needed in 12 (9.7\%) women from groups I and II [N = 124], but in as many as 47 (18.1\%) from groups III and IV [N = 260] (Tab. 4).

The prevalence of the different variants of $C L$, defined on the basis of histopathological diagnosis, is presented in Table 5. Table 6 includes detailed data on type, route and mode of the procedure/surgery in all groups of patients, while data on coexisting malignant tumors of the genital tract are presented in Table 7.

Table 8 includes detailed numeric data (with percentages) on the prevalence rates of $C L$ and partially cellular leiomyoma among the 2144 women undergoing procedures and surgeries due to uterine leiomyomas.

\section{DISCUSSION}

Among the 2144 women with uterine leiomyomas confirmed on histopathology, the total prevalence rate for $\mathrm{CL}$ and partially cellular leiomyomas was $17.9 \%$ (Tab. 8). Out of them, $\mathrm{CL}$ was found in $4.3 \%$ of the women. That rate reached $5.8 \%$ when $\mathrm{CL}$ cases with coexisting endometriosis (1.5\%) were taken into account, and $9.4 \%$ when $\mathrm{CL}$ cases with coexisting leiomyomas and/or partially cellular leiomyomas (3.6\%) were included. The $9.4 \%$ rate is 2 -fold higher as compared to the available literature.

In our study, there were 10 (2.6\%) cases of cellular leiomyomas in the uterine cervix, including 3 cases of $C L$ and 7 of partially cellular leiomyomas. In one woman, we simultaneously detected $\mathrm{CL}$ in the uterine cervix and partially cellular leiomyoma in the uterine corpus. The literature reports the prevalence rate for leiomyomas in the uterine cervix to be approximately $4-7 \%$ [20].

Table 1. Age of patients with leiomyomas

\begin{tabular}{|l|c|c|c|c|}
\hline $\begin{array}{l}\text { Groups 1-4 } \\
\text { Mean age: } \mathbf{4 7 . 6 6}\end{array}$ & Cellular leiomyoma (CL) & CL with endometriosis & $\begin{array}{c}\text { Partially cellular leiomyoma } \\
\text { and/or CL with leiomyoma }\end{array}$ & $\begin{array}{c}\text { Partially cellular leiomyoma } \\
\text { and/or CL with leiomyoma } \\
\text { and endometriosis }\end{array}$ \\
\hline Mean age (in years) & 47.24 & 50.78 & 45.97 & 49.47 \\
\hline Range & $26-76$ & $36-68$ & $31-75$ & $33-70$ \\
\hline SD & 9.52 & 9.24 & 8.76 & 8.14 \\
\hline
\end{tabular}

\begin{tabular}{|c|c|c|c|c|}
\hline $\begin{array}{l}\text { Groups 1-4 } \\
\text { Weight mean: } 70.72 \\
\text { BMI mean: } 26.66\end{array}$ & Cellular leiomyoma (CL) & CL with endometriosis & $\begin{array}{l}\text { Partially cellular leiomyoma } \\
\text { and/or CL with leiomyoma }\end{array}$ & $\begin{array}{l}\text { Partially cellular leiomyoma } \\
\text { and/or CL with leiomyoma } \\
\text { and endometriosis }\end{array}$ \\
\hline $\begin{array}{l}\text { Mean } \\
\text { Range } \\
\text { SD }\end{array}$ & $\begin{array}{c}69.21 \\
52-118 \\
12.03\end{array}$ & $\begin{array}{c}75.25 \\
52-140 \\
19.42\end{array}$ & $\begin{array}{c}70.52 \\
53-117 \\
13.31\end{array}$ & $\begin{array}{c}70.95 \\
48-122 \\
13.18\end{array}$ \\
\hline $\begin{array}{l}\text { Mean } \\
\text { Range } \\
\text { SD }\end{array}$ & $\begin{array}{c}25.86 \\
19.16-38.09 \\
4.05\end{array}$ & $\begin{array}{c}28.47 \\
21.33-44.19 \\
5.81\end{array}$ & $\begin{array}{c}26.63 \\
17.30-40.46 \\
4.67\end{array}$ & $\begin{array}{c}26.85 \\
19.37-39.39 \\
4.20\end{array}$ \\
\hline
\end{tabular}




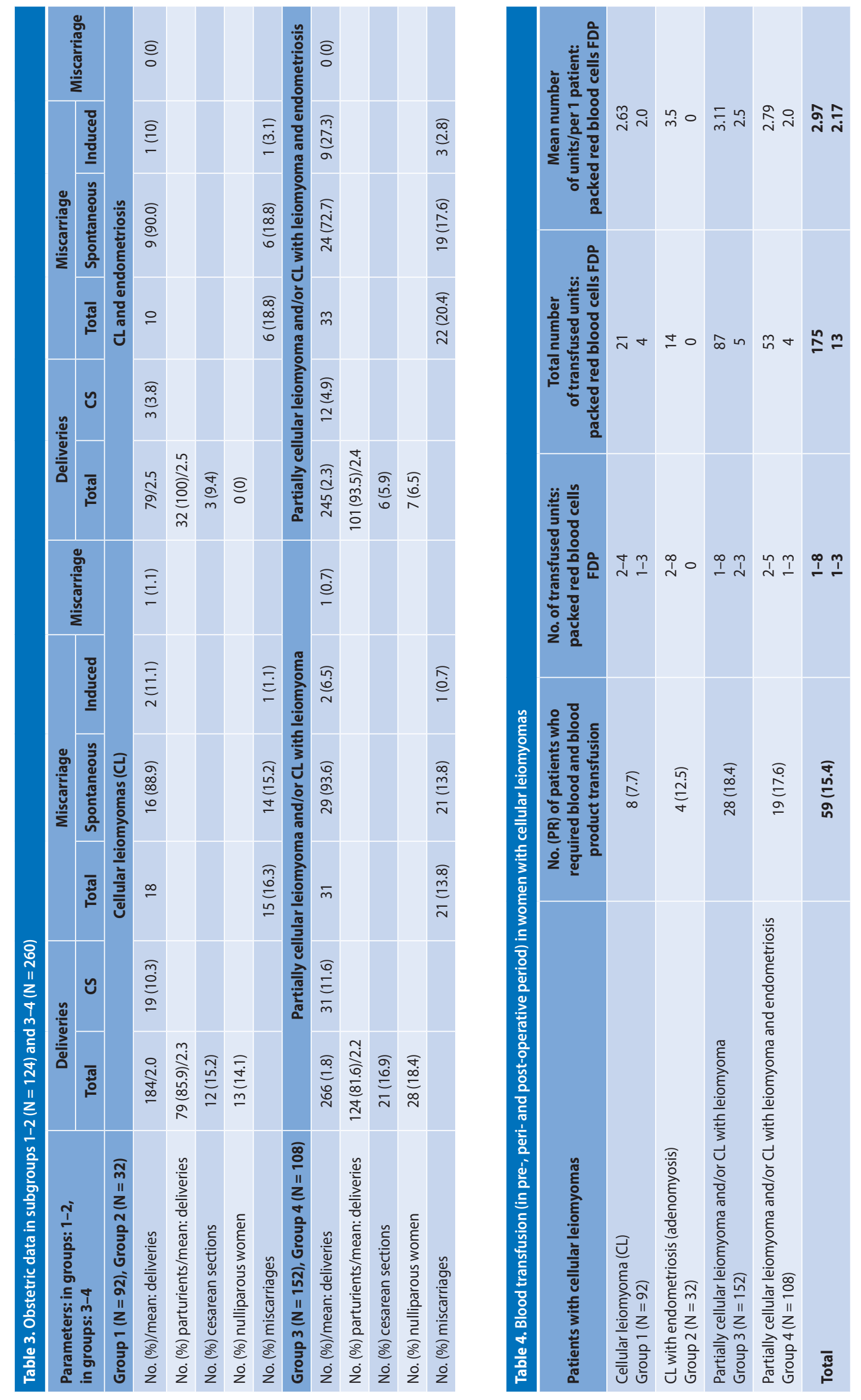



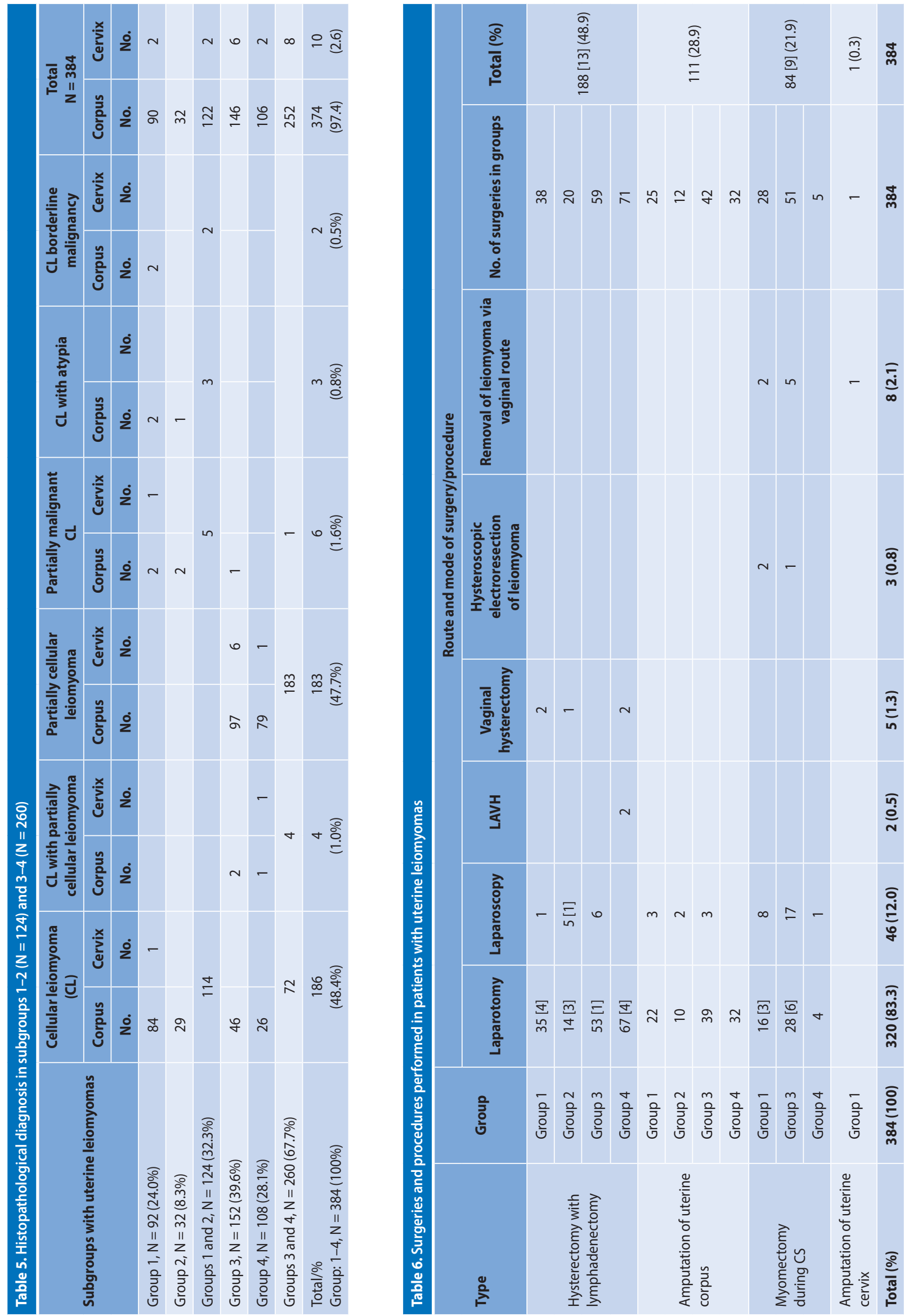
Table 7. Prevalence of malignant tumors in women with cellular leiomyomas

\begin{tabular}{|c|c|c|c|c|c|}
\hline \multirow{3}{*}{$\begin{array}{l}\text { Subgroups (1-4) with uterine leiomyomas } \\
(\mathrm{N}=384)\end{array}$} & \multicolumn{2}{|c|}{ Uterine malignancy } & \multirow{2}{*}{ Ovarian cancer } & \multirow{2}{*}{ Breast cancer } & \multirow{2}{*}{$\begin{array}{c}\text { Total } \\
(\%)\end{array}$} \\
\hline & Corpus & Cervix & & & \\
\hline & No. & No. & & & No. (\%) \\
\hline Cellular leiomyoma (CL), N = 92 & 3 & 1 & 2 & & $6(6.5)$ \\
\hline $\mathrm{CL}$ with endometriosis, $\mathrm{N}=32$ & 6 & & & $1[1]$ & $7(21.9)$ \\
\hline $\begin{array}{l}\text { Partially cellular leiomyoma and/or CL } \\
\text { with leiomyoma, } \mathrm{N}=152\end{array}$ & $3[1]$ & & 1 & & $4(2.6)$ \\
\hline $\begin{array}{l}\text { Partially cellular leiomyoma and/or CL } \\
\text { with leiomyoma and endometriosis, } \mathrm{N}=108\end{array}$ & 4 & $1[1]$ & 3 & & $8(7.4)$ \\
\hline Co-occurrence in different organs & $16[1]$ & $2[1]$ & 6 & $1[1]$ & $25(6.5)$ \\
\hline
\end{tabular}

[ ] - malignant neoplasms treated before surgery or diagnosed preoperatively

Table 8. Cellular leiomyomas (CL) and partially cellular leiomyomas among the 2144 cases with diagnosed uterine leiomyomas

\begin{tabular}{|c|c|c|c|c|c|c|c|c|c|}
\hline \multirow{3}{*}{$\begin{array}{l}\text { Subgroups with uterine } \\
\text { leiomyomas } \\
\text { No. and prevalence rate }\end{array}$} & \multicolumn{6}{|c|}{$\begin{array}{l}\text { Cellular leiomyomas }(\mathrm{CL})(\mathrm{N}=201) \\
\text { PR out of } 384:-52.3, \text { PR out of } 2144:-9.4\end{array}$} & \multirow{2}{*}{\multicolumn{3}{|c|}{$\begin{array}{l}\text { Partially cellular leiomyomas } \\
\qquad(\mathrm{N}=183)\end{array}$}} \\
\hline & \multicolumn{3}{|c|}{$\begin{array}{c}C L \\
(N=197)\end{array}$} & \multicolumn{3}{|c|}{$\begin{array}{l}\mathrm{CL} \text { - with partially } \\
\text { cellular leiomyomas } \\
(\mathrm{N}=4)\end{array}$} & & & \\
\hline & No. & $\begin{array}{l}\text { PR out } \\
\text { of } 384\end{array}$ & $\begin{array}{l}\text { PR out } \\
\text { of } 2144\end{array}$ & No. & $\begin{array}{l}\text { PR out } \\
\text { of } 384\end{array}$ & $\begin{array}{l}\text { PR out } \\
\text { of } 2144\end{array}$ & No. & $\begin{array}{l}\text { PR out } \\
\text { of } 384\end{array}$ & $\begin{array}{l}\text { PR out } \\
\text { of } 2144\end{array}$ \\
\hline Group 1, N = 92 (24.0\%) & 92 & 24.0 & 4.3 & & & & & & \\
\hline Group 2, N = 32 (8.3\%) & 32 & 8.3 & 1.5 & & & & & & \\
\hline Groups 1 and 2, N = 124 (32.3\%) & 124 & 32.3 & 5.8 & & & & & & \\
\hline Group 3, N = $152(39.6 \%)$ & 47 & 12.2 & 2.2 & 2 & 0.5 & 0.09 & 103 & 26.8 & 4.8 \\
\hline Group 4, N = 108 (28.1\%) & 26 & 6.8 & 1.2 & 2 & 0.5 & 0.09 & 80 & 20.9 & 3.7 \\
\hline Groups 3 and 4, N = 260 (67.7\%) & 73 & 19.0 & 3.4 & 4 & 1.0 & 0.2 & 183 & 47.7 & 8.5 \\
\hline Total & 197 & 51.3 & 9.2 & 4 & 1.0 & 0.2 & 183 & 47.7 & 8.5 \\
\hline
\end{tabular}

$\mathrm{PR}$ - prevalence rate

Among pregnant women, the prevalence rate for uterine leiomyomas has been estimated at 1.5-7.5\%. Myomectomy during cesarean section is indicated only in selected cases [21]. In our study, myomectomy was performed in 84 (21.9\%) women. Nine (2.3\%) myomectomies were performed during cesarean section, including 4 cases of $\mathrm{CL}$ (Tab. 6). To the best of our knowledge, the literature offers no reports on the prevalence of $\mathrm{CL}$ removed during cesarean delivery. Also, data on the coexistence of endometriosis with cellular leiomyomas of the uterus are unavailable - in our study, the rate was $36.5 \%$. Concomitant endometriosis and leiomyomatosis was reported by Taran et al., in $20 \%$ out of the 1955 women undergoing surgery [22].

According to the literature, mean age of patients with postoperative diagnosis of cellular leiomyomas is lower as compared to women undergoing surgery due to leiomyomas. In our study, mean patient age was calculated at $47.7 \%$, and was higher than reports from Guan et al., and Taran et al., 45.3 and 44.7 years, respectively $[18,23]$.
Mean weight in our study was $70.7 \mathrm{~kg}$, and no significant differences were found between the four subgroups. A statistically significant difference in BMI was observed only between patients from groups I and II (Tab. 2). Apart from ethnicity, risk-promoting factors for the development of myomas include age, obesity, and genetic factors. Taran et al., found a BMI of 28.3 in 99 women with confirmed cellular myomas [23].

Obstetric data (delivery, miscarriage, ectopic pregnancy) are presented in Table 3. Out of 336 parous women, mean parity was 2.3 (ranging from 2.2 to 2.5 in the studied groups). Interestingly, the rate of nulliparous women (16.8\%) in groups I and III - only with uterine leiomyomas, without endometriosis ( $\mathrm{N}$-244) was over 3-fold higher than the rate reported in groups II and IV (5\%) - uterine myomas with concomitant endometriosis of the uterine corpus (N-140). Additionally, lower rate of cesarean sections was observed in women from groups II and IV - with concomitant endometriosis. Taran et al., in some of the cited sources, found a higher number of cesarean sections in women with adenomyosis [22]. 
The risk for developing uterine leiomyomas according to various authors is 2-fold higher in case of infertility, and 5 -fold lower in multiparas ( $>5$ ) as compared to nulliparas. The literature reports the prevalence rate for uterine fibroids in infertile subjects to range between $1 \%$ and $2.4 \%$. The correlation between infertility and uterine leiomyomas remains to be fully elucidated. Randomized studies are necessary to determine the possibility of uterine leiomyomas being the cause of infertility [24]. In our study, the higher rate of nulliparous women in groups without concomitant endometriosis, in the majority of cases 141 (57.8\%) with CL, may be associated with the reported higher weight of the fibroids, which might be responsible for infertility or miscarriage [23].

Dyląg et al., concluded that blood and its products may be used in patients with the diagnosis of leiomyoma, treated at the Division of Obstetrics and Gynecology of a clinical and district hospital $-6.6 \%$ and $8.2 \%$, respectively [25]. In our study, the high rate (15.4\%) of blood transfusions among women undergoing surgery for uterine leiomyomas was undoubtedly connected with the higher weight of $\mathrm{CL}$ - reported in the literature - resulting in surgical challenge and consequent more perioperative blood loss [23].

The distribution of various $C L$ histopathological variants has been presented in detail in Table 5. Histopathological results include partially malignant $\mathrm{CL}, \mathrm{CL}$ with atypia, and borderline malignant $\mathrm{CL}$. The available literature mentions borderline $\mathrm{CL}$ and transformation to LMS also in other organs of the genital and urinary tract $[11,18]$.

Numerous authors concluded that cellular leiomyomas possess a separate - as compared to typical leiomyomas - clinical phenotype and common genetic features with LMS $[23,26,27]$. Deletion of chromosome $1 p$ - characteristic of LMS - was also found in the CL subtype in 23\% of the cases. That genetic modification is associated with potentially malignant nature of cellular leiomyomas. The presence of that pathology is an important element in the decision-making process about conservative treatment and clinical supervision [27].

Our histopathological analysis detected cases of borderline CL (Tab. 5). Additionally, partially cellular leiomyoma in the right uterus and LMS in the left uterus were found in one patient with two uteruses and vaginas (R.M., aged 71). Also, our clinical observations and histopathology results suggest the possibility of CL transformation to LMS. According to the available literature, that risk ranges from $0.1 \%$ to $0.8 \%$ [28].

Two cases of intravenous leiomyomatosis, which is a particularly rare type of myometrial invasion, were found among our patients. Du et al., reported a 33.3\% rate of cellular leiomyomatosis in their study of intravenous leiomyomatosis [29]. Hemorrhagic cellular leiomyoma was observed in cases of myomectomy performed during a cesarean section. The recurrence rates among patients after myomectomy were reported by various studies, e.g. $28.6 \%$ and $8 \%$ [18, 23]. Also, recurrence was also reported after total radical hysterectomy $[26,30]$.

Implantation metastases - even after several decades since myomectomy or hysterectomy - have been reported also in cases of CL. Their incidence is similar to that of leiomyoma. The most common metastatic sites include the lungs, but also skeletal muscles, heart, bone marrow, and the peritoneal cavity - often, they pose a direct threat to the patient life. A case of death due to malignant transformation after surgery was reported in a patient with diagnosed $\mathrm{CL}$ $[23,26,30]$. Dong et al., reported a case of cellular leiomyoma accompanied by Pseudo-Meigs syndrome [31]. The abovementioned clinical observations indicate that $\mathrm{CL}$ should not be treated as a tumor with a benign course $[26,30]$.

In our study, a total of 299 (77.8\%) hysterectomies - with lymphadenectomy, simple and subtotal - were performed in 13 (3.4\%), 175 (45.5\%) and 111 (28.9\%) women (Tab. 6). In case of cellular leiomyomas, high rates of hysterectomies were connected with the recent recommendations of more radical surgical treatment. Earlier studies claimed that the risk for malignant transformation is no indication for hysterectomy. Concomitant malignant tumors of the genital tract were found in $26(6.8 \%)$ of the patients undergoing surgery, out of them $16(4.2 \%)$ in the uterine corpus, including 11 (2.9\%) with CL and 5 (1.3\%) with partially cellular leiomyoma (Tab. 7).

Significant differences were found in the prevalence of malignant tumors of the genital tract between women with and without coexisting endometriosis. In our study, endometriosis was found in 140 (36.5\%) cases: 60 (29.9\%) among 201 patients with CL and 80 (43.7\%) among 183 patients with partially cellular leiomyoma. Taran et al., observed concomitant endometriosis in $8.1 \%$ of the women with CL [23]. Malignant transformation of endometriosis was reported already in 1925 by Sampson, mainly in cases of ovarian cancer, but also other fragments of the genital tract, including endometrial adenocarcinomas [32]. In our study, CL and partially cellular leiomyoma with concomitant endometriosis of the uterine corpus - concomitant malignancy - were found in $10.7 \%$ of the 140 women undergoing surgery in groups II and IV, whereas in groups I and III - without endometriosis of the uterine corpus - the rate was $4.5 \%$ of the 244 women. As for the malignancy of the uterine corpus, the rates were $7.1 \%$ and $2.5 \%$ in the same groups, while in the groups with concomitant endometriosis of the uterine corpus the values more than doubled (Tab. 7).

In light of the borderline pathological nature of $\mathrm{CL}$ and reported cases of malignant transformation of other rare histological subtypes of leiomyomas, e.g. lipoleiomyoma, recent years have seen a visible shift in opinions of many researchers, who postulate a longer clinical supervision of patients treated 
for CL. Hysterectomy, followed by clinical supervision, ought to become a standard [18,30]. Strict clinical supervision after conservative management is recommended at the very least for women in the reproductive age who wish to preserve their fertility [26]. Thus, it seems prudent to resort to conservative management only in the following cases: patient's wish to conceive, lack of consent for surgery, or specific circumstances when surgery is deemed impossible $[18,26]$.

Attempts to use genetic therapy for treating uterine leiomyomas have also been made. The results of studies on animal models, using genetic therapy to inactivate the estrogen receptor which leads to cell apoptosis and modulates ECM proliferation of the leiomyoma, generated promising results $[33,34]$.

Interdisciplinary cooperation of various specialists, including scholars in the field of basic research, is required in order to advance the diagnostic process and treatment of uterine leiomyomas, including cellular leiomyomas.

\section{CONCLUSIONS}

Histopathology reports of $\mathrm{CL}$ cases with varying degrees of atypia, combined with the collected clinical data, in the literature indicate the possibility of malignant transformation of cellular leiomyomas and partially cellular leiomyomas to leiomyosarcomas. Hysterectomy, followed by clinical supervision, ought to become a standard in the treatment of cellular leiomyomas. Conservative management - myomectomy - should be reserved for patients who wish to preserve their fertility, refuse surgical treatment, or in cases when surgery is deemed impossible.

\section{REFERENCES}

1. Auguściak-Duma A, Sieroń AL. Molekularna charakterystyka guzów leiomyoma uteri na przykładzie wybranych składników macierzy pozakomórkowej. Postępy Hig Med Dośw. 2008, 62, 148-165.

2. Canevari RA, Pontes A, Rosa FE, [et al.]. Independent clonal origin of multiple uterine leiomyomas that was determined by $\mathrm{X}$ chromosome inactivation and microsatellite analysis. Am J Obstet Gynecol. 2005, 193, 1395-1403.

3. Fernandes $\mathrm{H}$, Naik CN, Swethadri GK, [et al.]. Pure lipoma of the uterus: A rare case report. Indian J Pathol Microbiol. 2007, 50, 800-801.

4. Ligon AH, Morton CC. Genetics of uterinae leiomyoma. Genes Chromosomes Cancer. 2000, 28, 235-245.

5. Dębski R, Kotarski J, Paszkowski T, [et al.]. Stanowisko Zespołu Ekspertów Polskiego Towarzystwa Ginekologicznego w sprawie zastosowania selektywnych modulatorów receptora progesteronowego (SPRM) w leczeniu mięśniaków macicy. Ginekol Pol. 2012, 83, 555-557.

6. Sozen I, Arici A. Interaction of cytokines, growth factors, and the extracellular matrix in the cellular biology of uterinae leiomyomata. Fertil Steril. 2002, 78, 1-12.

7. Stewart EA, Morton CC. The genetics of uterine leiomyomata: what clinicians need to know. Obstet Gynecol. 2006, 107, 917-921.

8. Chang CC, Hsieh YY, Lin WH, [et al.]. Leiomyoma and vascular endothelial growth factor gene polymorphisms: a systematic review. Taiwan J Obstet Gynecol. 2010, 49, 247-253.

9. Toro JR, Nickerson ML, Wei MH, [et al.]. Mutations in the fumaratehydratase gene causa hereditary leiomyomas and renal cell cancer in families in North America. Am J Hum Genet. 2003, 73, 95-106.
10. Czapczak D, Markowska A, Piatkowska M, [et al.]. Nosicielstwo mutacji w eksonie 6 genu NBS1 a ryzyko zachorowania na mięśniaki macicy. Nowotwory J Oncol. 2011, 61, 109-113.

11. Hodge JC, Pearce KE, Clayton AC, [et al.]. Uterine cellular leiomyomata with chromosome $1 \mathrm{p}$ deletions represent a distinct entity. Am J Obstet Gynecol. 2014, 210, 527, e1-e7.

12. Lobel MK, Somasundaram P, Morton CC. The genetic heterogeneity of uterine leiomyomata. Obstet Gynecol Clin North Am. 2006, 33, 13-39.

13. Hoffman PJ, Milliken DB, Gregg LC, [et al.]. Molecular characterization of uterine fibroids and its complication for underlying mechanisms of pathogenesis. Fertil Steril. 2004, 82, 639-649.

14. Luo X, Ding L, Xu J, [et al.]. Gene expression profiling of leiomyoma and myometrial smooth muscle cells in response to transforming growth factor. Endocrinology. 2007, 146, 1097-1118.

15. Laping NJ, Everitt Jl, Frazier KS, [et al.]. Tumor-specific efficacy of trans forming growth factor-beta RI inhibition in Eker rats. Clin Cancer Res. 2007, 13, 3087-3099.

16. Halder SK, Goodwin JS, Al-Hendy A. 1,25-Dihydroxyvitamin D3 reduces TGF- $\beta 3$-induced fibrosis-related gene expression in human uterine leiomyoma cells. J Clin Endocrinol Metab. 2011, 96, E754-E762.

17. Norian JM, Malik M, Parker CY, [et al.]. Transforming growth factor beta3 regulates the versican variants in the extracellular matrix-rich uterine leiomyomas. Reprod Sci. 2009, 16, 1153-1164.

18. Guan R, Zheng W, Xu M. A retrospective analysis of the clinicopathologic characteristics of uterine cellular leiomyomas in China. Inter J Gynecol Obstet. 2012, 118, 52-55.

19. Madej P, Madej JA. Patomorfoza mięśniaków macicy u kobiet. Gin Pol Med. Project. 2008, 3, 32-42.

20. Taran FA, Stewart EA, Brucker S. Adenomyosis: Epidemiologie, risikfaktoren, klinisches erscheinungsbild sowie chirurgische und interventionelle alternative zur hysterectomie. Geburtsh Frauenheilk. 2013, 73, 924-931.

21. Taran FA, Weaver AL, Gostout BS, [et al.]. Understanding cellular leiomyomas: a case-control study. Am J Obstet Gynecol. 2010, 203, 109, e1-e6.

22. Farguhar C, Arroll B, Ekeroma A, [et al.]. Anevidence-based guideline for the management of uterine fibroids. Aust NZJ Obstet Gynaecol. 2001, 41, 125-140.

23. Dylag S, Kucharz EJ. Wykorzystanie krwi i jej składników w dwóch oddziałach ginekologiczno-położniczych szpitali województwa śląskiego w latach 1996-2002. Pol Merk Lek. 2011, 30, 195-2001.

24. Musierowicz A, Chilimoniuk M, Matejczuk A, [et al.]. Przypadek zezłośliwiałego mięśniaka gładkokomórkowego pęcherza moczowego. Urol Pol. 1978, 3, 3.

25. Guraslan H, Senturk MB, Helvacioglu C, [et al.]. Recurent cellular leiomyoma 10 years after total abdominal hysterectomy. J Obstet Gynaecol. 2015, 35, 854-855.

26. Markowska A, Słomko Z. Mięśniaki macicy. In: Słomko Z (ed.). Ginekologia. PZWL, Warszawa 2008, 148-165.

27. Du J, Zhao X, Guo D, [et al.]. Intravenous leiomyomatosis of the uterus: A clinicopathologic study of 18 cases, with emphasis on early diagnosis and appropriate treatment strategies. Hum Pathol. 2011, 42, 1240-1246.

28. Rothmund R, Kurth RR, Łukasińska NM, [et al.]. Clinical and pathological characteristics, pathological reevaluation and recurrence patterns of cellular leiomyomas: a retrospective study in 76 patients. Eur J Obstet Gynecol Reprod Biol. 2013, 171, 358-361.

29. Dong R, Jin C, Zhang Q, [et al.]. Cellular leiomyoma with necrosis and mucinous degeneration presenting as pseudo-Meigs' syndrome with elevated CA 125. Oncol Rep. 2015, 33, 3033-3037.

30. Pośpiech-Gąsior K. Wpływ mięśniaków macicy na przebieg ciąży, porodu oraz połogu. Rozprawa doktorska. Kraków 2011. Pozyskano z dl.cm-uj. krakow.pl:8080/Content/3402.

31. Emerich J. Operacyjne leczenie mięśniaków. In: Markowska J (ed.). Mięśniaki macicy. Wydawnictwo MedPharm Polska, Wrocław 2008, 73-83.

32. Markowska J. Endometrioza a procesy nowotworowe. In: Radowicki S, Szyłło K (eds.). Endometrioza. Diagnostyka i leczenie. Wydawnictwo Edra Urban \& Partner, Wrocław 2016, 249-252.

33. Al-Hendy A, Salama S. Gene therapy and uterine leiomyoma: a review. Human Reprod Update. 2006, 12, 385-400.

34. Hassan MH, Salama SA, Zhang D, [et al.]. Gene therapy targeting leiomyoma: adenovirus-mediated delivery of dominant-negative estrogen receptor gene shrinks uterine tumors in Eker rat model. Fertil Steril. 2010, 93, 239-250. 